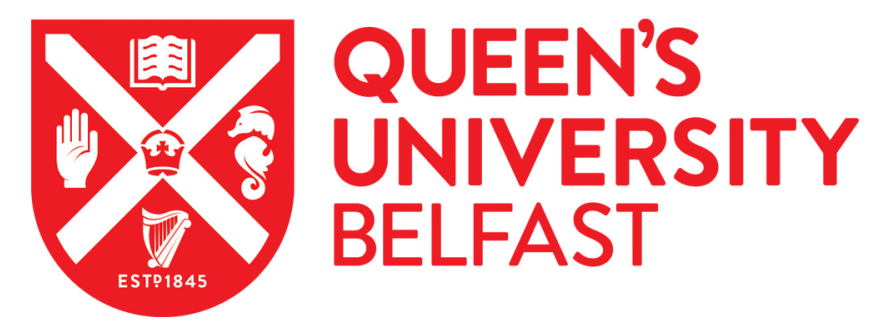

\title{
The Quaternary of the Jurassic Coast Region: From The Neogene to the Anthropocene
}

\author{
Brown, A. G., Basell, L. S., \& Toms, P. S. (2018). The Quaternary of the Jurassic Coast Region: From The \\ Neogene to the Anthropocene. Proceedings of the Geologists' Association. \\ https://doi.org/10.1016/j.pgeola.2018.02.005
}

\section{Published in:}

Proceedings of the Geologists' Association

\section{Document Version:}

Peer reviewed version

\section{Queen's University Belfast - Research Portal:}

Link to publication record in Queen's University Belfast Research Portal

\section{Publisher rights}

() 2018 The Geologists' Association. Published by Elsevier Ltd. All rights reserved.

This manuscript is distributed under a Creative Commons Attribution-NonCommercial-NoDerivs License

(https://creativecommons.org/licenses/by-nc-nd/4.0/), which permits distribution and reproduction for non-commercial purposes, provided the author and source are cited.

\section{General rights}

Copyright for the publications made accessible via the Queen's University Belfast Research Portal is retained by the author(s) and / or other copyright owners and it is a condition of accessing these publications that users recognise and abide by the legal requirements associated with these rights.

Take down policy

The Research Portal is Queen's institutional repository that provides access to Queen's research output. Every effort has been made to ensure that content in the Research Portal does not infringe any person's rights, or applicable UK laws. If you discover content in the Research Portal that you believe breaches copyright or violates any law, please contact openaccess@qub.ac.uk. 


\title{
The Quaternary Rivers of the Jurassic Coast Region: from the Neogene to the Anthropocene
}

\author{
A. G. Brown ${ }^{\text {a }}$, L. S. Basell ${ }^{\text {, P. P. Toms }}{ }^{c}$

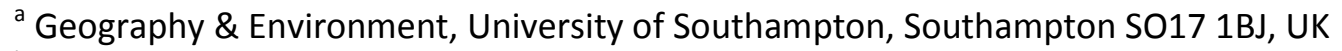 \\ ${ }^{\mathrm{b}}$ Archaeology \& Palaeoecology, School of Natural and Built Environment, Queens University, Belfast \\ BT7 1NN, UK \\ ${ }^{\mathrm{C}}$ Luminescence dating laboratory, School of Natural and Social Sciences, University of \\ Gloucestershire, Swindon Road, Cheltenham GL50 4AZ UK
}

\begin{abstract}
The Jurassic Coast World Heritage Sites (JCWHS) is not only a $95 \mathrm{~km}$ long coastline and remarkable Mesozoic geological section, but also a slice through a Quaternary landscape. For the majority of the last two million years this landscape lay in the periglacial zone, just south of a waxing and waning ice margin and just north of an Atlantic inlet which eventually became the English Channel. This paper reviews how the previous landscape inherited from the Cenozoic, was modified through uplift, climatically driven fluvial activity and periglaciation. Much evidence of this Quaternary history can be been today in sections along the JCWHS coast which is cuts through a number of headwater valleys the largest of which are the Exe and Axe. Recent studies, largely funded from the Aggregate Levy Tax, have produced the first independent chronologies for the Exe and Axe valleys and a model of how periglaciation interacted with the layer-cake stratigraphy of the Mesozoic bedrocks of the JCWHS. The Quaternary history of the JCWHS is also preserved in raised beaches on the Isle of Portland, coastal landforms, and in Holocene alluvial sediments associated with human activity and which may constitute part of the putative Anthropocene. An appreciation of the Quaternary history of the JCWHS is also important in understanding modern geological hazards from landslides to flooding.
\end{abstract}

Keywords: landforms, periglaciation, coastal evolution, river gravels, alluviation, Palaeolithic archaeology

\subsection{Introduction}

This paper collates and summarizes recent and new research on the Quaternary geology of the Jurassic Coast World Heritage Site (JCWHS) with special emphasis on fluvial-coastal interactions rather than Holocene coastal and submarine evolution which is covered by May (2017). Until recently this was an under-researched area, due to its intermediate position between the Hampshire-Solent Basin to the East, and the Cornubian Massif to the west. Indeed it is one of the few areas in the UK not covered by a Quaternary Association Field Guide with the geographically nearest being the two guides to Wessex and the Isle of Wight to the east (Barber, 1987; Bryant et al., 2009), and the more recent guide to the Exe Valley and Adjoining Areas to the West (Basell et al., 2011). It can also be argued that, by definition a coastline is a relatively transient (short-lived) zone in geological terms. Over the Tertiary and Quaternary it has retreated several kilometers and much of its Quaternary history has been lost through erosion as illustrated by classic erosional landforms such as the arch at Durdle Dor, Lulworth Cove and almost total erosion of the Lulworth Banks Anticline (Sanderson et al., 2017), although the timescale involved is basically unknown. The lateral rate of erosion is also likely to have been variable since the lithology of the coastal cliffs and shore platforms changes along the coastline (Sanderson et al., 2017) as indicated by the overall planform and protrusion of more resistant lithologies such as the Portland Limestones of Portland Island and Bill and the enhanced erosion at fault zones such as the Axe valley fault zone. Lithologically and tectonically related 
variations in the rate in cliff retreat are known to be a major factor producing regional supralandform such as capes and bay coastlines like the JCWHS (Cosgrove et al., 1998). The coast also spans an important drainage divide that has been truncated by this geologically recent erosion (May, 2017).

The history of regional landscape change is important in relation to any interpretation of the coastal dynamics. The Jurassic Coast has been formed $80-100 \mathrm{~km}$ to the south of the maximum extent of the Devensian (Weichselian, marine isotope stage (MIS) 4-2) ice sheet which reached the Bristol Channel (Rolfe et al. 2012; Hughes and Gibbard, 2014), and probably only $60 \mathrm{~km}$ south of the maximum extent of an ice sheet during the Anglian (Elsterian, MIS 12), or earlier. It was, however, subject to intense periglaciation (but not paraglaciation since the area was never glaciated) with continuous permafrost for the majority of the Quaternary and this is recorded in both its fluvial, and sloperelated landforms (Brown, 2012). To the south and west the Atlantic Ocean also had a profound effect. Most obviously the Atlantic was directly involved in the creation of the cliff-line and coastal features such as Chesil Beach, but its effect on regional climate and the biogeographical distribution of plants and animals would also have affected the coast indirectly.

\subsection{Fluvial systems and drainage evolution}

Only two medium sized alluvial rivers enter the English Channel through the Jurassic Coast - the Exe $\left(1530 \mathrm{~km}^{2}\right)$ which forms the western boundary of the JCWHS and which drains mid Devon (including the Crediton Basin), and parts of the Blackdown Hills, Dartmoor and Exmoor, and to the east, the Axe $\left(300 \mathrm{~km}^{2}\right)$ which drains the remainder of the Blackdown Hills. Smaller rivers (west to East) such as the Otter, Sid, Lim (draining to Lyme Regis), the Char and Brit (or Brede) are headwater tributaries of the Exe and Axe systems, (including the strike aligned dry valley system "Scratchy Bottom" that runs into Lulworth Cove). The JCWHS is also bounded to the east by Poole Harbour which is the estuary of the Frome-Piddle fluvial system and drains the southern part of the Wessex plateau. For much of the Cenozoic (Tertiary), the region had a prominent drainage divide with the Exe and Axe forming a single system which drained westwards to the Atlantic Ocean, whilst the section to the east of the Isle of Portland drained into the Solent system, which also drained into the Atlantic but via the central part of the English Channel (Fig. 1). When this divide formed is not exactly known but it is of structural origin, and was probably created during the early Alpine orogeny. It was also the Alpine orogeny which created the geological structure (persistent flexuring) that underlies the Isle of Portland (Brunsden et al., 1996; Gibbard and Lewin, 2003; Brown, 2016) and the structure of the Hampshire Basin to the east. Remarkable recent high-resolution bathymetry from Weymouth Bay suggests that prior to basin inversion (uplift) the basin evolved by intermittent activity on a few major extensional faults (Sanderson et al., 2017). Overall the region has undergone moderate netuplift through the late Pleistocene of between $6 \mathrm{~m}$ and $11 \mathrm{~m}$ west to east (Westaway, 2010, 2011) and about $60 \mathrm{~m}$ over the last 0.5 million years. The result of this combined climatic and tectonic history has been valley incision and cold-stage gravel deposition. There is a large variation in the number of morphologically distinct Pleistocene terraces - numbering from 8-10 in the Exe and Otter systems in the west, to 2 in the Axe valley and then to 14-15 in the Frome-Piddle system (which is the largest number in the UK) (Fig. 2; Brown et al., 2009). This is largely the result of variations in catchment geology affecting the style of terrace system formation sensu Lewin and Gibbard (2010), as discussed in more detail in the Exe section of this paper. This evolution combined with progressive retreat of the coast line meant that by the Middle Pleistocene, most of the length of the JCWHS was characterized by relatively steep, southward flowing, short rivers bisecting the cliff-line in V-shaped valleys including Scatchy Bottom dry valley. 
Research in the last decade has increased considerably, due to The Palaeolithic Rivers of South West Britain Project (PRoSWeB) funded by the Aggregates Levy Sustainability Fund (ALSF) and administered by English Heritage (ALSF-EH). This funding permitted the identification of new sites, and importantly it funded attempts at dating control on some of the fluvial terrace sequences in the region largely using optically stimulated luminescence (OSL) (Basell et al., 2007; Brown et al., 2010; Toms et al., 2011). This work has been continued in the Axe valley with funding from English Heritage under the Historic Environment Enabling Programme (HEEP) (Basell et al., 2011a,b; Toms et al., 2013; Brown et al., 2014). The area has been the focus of few other geoarchaeological research programs over the last decade; an exception being the Community Landscape Project which was funded by the Heritage Lottery Fund and funded palaeoecological and archaeological studies in East Devon (Brown et al., 2014).

The methods used in the ALSF-EH studies included relatively standard techniques of ground survey, LiDAR, geophysics (ground penetrating radar (GPR)), exposure logging, pollen analysis (at Chard Junction and Kilmington Quarry), OSL and granulometry. Two relatively innovatory techniques were also used at Chard Junction quarry in the Axe valley: down-well gamma spectrometry logging and terrestrial laser scanning (TLS). The reader is referred to the original papers for further information on these methods (Brown et al., 2010, 2014a; Basell et al., 2011b). Valley evolution is not only important in generating the topography of the coastline but also in providing large amounts of sediment especially during cold stages which can then be eroded and partially redistributed in warm high relative sea level periods such as the present interglacial (Holocene).

\section{The Exe Catchment}

The terrace staircase of the upper to middle Exe valley, which extended into a buried valley under the Holocene estuary, has been recognized for many years (Kidson, 1962; Durrance 1969, 1980), but lacked chronological control largely due to the lack of any faunal remains which may be due to decalcification of the gravels by mildly acidic groundwater in comparison with gravels on carbonate lithologies where bone preservation is common (e.g. The River Nene in eastern England, Brown 2004). However, between 2005 to 2008 a new study was undertaken in the Exe Valley with the aim of providing an understanding the response of SW England to long-term climate change, and also in order to provide a chronological and environmental context for human artefacts found within some of the terrace gravels (Brown et al., 2010). The work used a combination of trenching, geophysics (largely GPR), OSL dating and terrace mapping. The Exe terrace staircase contains gravels with significant variation in form, sedimentology and clast lithology. The observation was made whilst mapping the upper terraces (8-6) that they appeared to overlap, and were probably composite (or multi-storey cf. Gibbard and Lewin, 2003), and had been deposited in several cold phases of the Middle Pleistocene (Edwards and Scrivener, 1999). This is supported by the discovery of sarsens on strath terrace (Basell et al. 2011a). These large (several tons) blocks of silicified rock are most likely to have been derived from periglacial erosion of the Tertiary plateau gravels in the region, and could have been plinthites on the valley edges of the plateaus. Terrace 6 of the Exe is up to $3.5 \mathrm{~m}$ thick and composite in the Netherexe Basin. Terrace fragments were frequently heavily truncated as at Princesshay in the City of Exeter (T6), and all showed varying degrees of cryoturbation. It is also clear from the mapping and depth data that the lowest 3 terraces have little vertical separation and are inset into each other forming the valley floor. Many of these stratigraphic relationships of the higher terraces can be seen in the East Devon coastal sections from Exmouth to Ladram Bay.

The Exe OSL dating programme had variable results, with more intrinsically reliable results for the lower terraces (Table 1). One problem identified was that high dose rates in the Middle Exe area can cause saturation of the OSL signal (due to high intrinsic dose rates) making dating beyond 70 thousand years before present (Kyr BP) problematic. However, the first OSL based estimates were that the lower four terraces of the Exe were deposited during the Devensian with terrace 4 in the 
early Devensian (MIS 4), terrace 3 in the Middle Devensian (MIS 3) - both pre-dating the Last Glacial Maximum (LGM), and terraces gravels 2 and 1 after the LGM in the Late Devensian (MIS 2, Worth Wood). The marked incision between terraces 4 on the Exe and the lower inset or floodplain terraces (1-3) would appear to date to between $60 \mathrm{Kyr}$ BP and $30 \mathrm{Kyr} \mathrm{BP}$ (MIS 4-3) and the incision into terrace 3 and 2 in both the Exe and the Culm occurred during the LGM (Bennett et al., 2011). This suggests that the Late Pleistocene terrace evolution was principally controlled by Milankovitch forcing through accentuated cold-stage aridity (Briant et al., 2004). The higher terraces are more problematic and further dating is underway but the Early Devensian (MIS 4) dates obtained provide a minimum date for the Exe Terraces 4 and above. These higher terraces may have been formed in a similar manner after channel-depth incision during MIS 6 or early in MIS 4. The form of the terraces their extent, sedimentology and clast lithological properties have been combined to produce a 2D evolutionary model for the Lower Exe (Fig. 3) (Brown et al., 2010).

This model (Fig. 3) emphasizes the importance of lateral erosion (planation) and the incorporation of higher level, preceding, terrace gravels into lower terraces. The model is of a cyclic cascade driven by climate change, periglacial processes and uplift. The cascade is initiated from an upper terrace system which although undated is of probably of early-mid Pleistocene age and which occupied swathes of lowlands along the present valley course of up to $20 \mathrm{~km}$ in width. It follows that the valley topography approximately $140 \mathrm{~m}$ above the floodplain (or 60-75 m above sea level in the Netherexe Basin) is probably Middle-Late Pleistocene in age. It includes many landscape features such as the dry valley systems which grade to the main valley, small tributary valleys, emergent interfluves some gravel capped, and the confinement of river junctions. In particular the steep dry valleys typical in and around the City of Exeter bisect terraces 5 and 4 but grade into terrace 3 and contain solifluction deposits (Head) resting above terrace 3 gravels. This implies a mid-Devensian date for both their erosion and the deposits they contain. Palaeolithic artefacts are known to be associated with terraces 5 (and 4) of the Exe, predate MIS 4 and are probably considerably older than this (Brown et al., 2010). The direct implication of this work for the JCWHS is that at the western end the JCWHS has undergone moderate incision driven by both uplift and Pleistocene climatic oscillations and this has created the cliff-line profile that we see today from Exmouth to West Down Beacon (Fig. 1) which has retreated several kilometres (based in the River Otter terraces preserved at Ladram Bay (Basell et al. 2011a)) over approximately the last 0.5 Ma during periods of high relative sea level. This generated large amounts of flint and pre-rounded gravel which contributed to the coastal system.

\subsection{The Axe catchment}

Funding, initially from the same source (ALSF-EH) allowed similar work in the Axe Valley, $28 \mathrm{~km}$ to the east but with the addition of a terrestrial laser scanning (TLS) survey methodology for rapid recording of the exposures at the major site, Chard Junction (the only working Quaternary gravel quarry in the region). The valley had also been studied more recently than the Exe due to; a) its significance in debates concerning the glacial history of SW England (Green, 1974, 2013; Campbell et al., 1998a), and b) a major Palaeolithic site (Broom) known from the $19^{\text {th }}$ century. Broom is one of the super-sites in the British Palaeolithic (Hosfield and Green, 2013: Brown et al., 2013). So although the glacial drainage hypothesis had been disproven (Green et al., 1974) the extent and nature of the gravels was still anomalous (Brown et al., 2014a).

The most common model of mid-latitude late Quaternary terrace sequences, is that they are upliftdriven (or facilitated) but climatically controlled terrace staircases. Terrace formation is also influenced by both regional-scale crustal and tectonic factors, and palaeohydrological variations forced by quasi-cyclic climatic conditions over the last 900,000 years or since the Mid Pleistocene Transition (Elderfield et al. 2012). This model appears to hold for the majority of the river valleys draining into the English Channel including those in the JCWHS which exhibit 8-15 terrace levels over 
approximately $60-100 \mathrm{~m}$ of altitudinal elevation. However, as previously mentioned and shown in Fig. 2 and Fig. 4, the Axe has only one major (and one minor) morphological terrace and has long-been regarded as anomalous (Green, 1974). The study by Brown et al. (2014) demonstrated that this terrace is a stacked sedimentary sequence of 20-30 m thickness with a quasi-continuous (i.e. with hiatuses) pulsed, record of fluvial and periglacial sedimentation over at least the last 300-400 Kyr as determined principally by OSL dating of the upper two thirds of the sequence (Table 1). Since uplift has been regional, there is no evidence of anomalous neotectonic activity along the JCWHS, and climatic history must be comparable to the rest of the JCWHS, a catchment-specific mechanism is required to explain this stacked sequence. The Axe is the only valley in north west Europe incised entirely into the near-horizontally bedded and fractured chert (crypto-crystalline quartz) and sandrich Lower Cretaceous rocks (Upper Greensand) all of which are easily eroded under periglacial conditions.

Mapping of the valley slopes has identified many large arcuate landslide scars associated with past and present springs. It is proposed that these are thaw-slump scars (c.f. Gallagher, 2014) and represent large hill-slope failures caused by Vauclausian (from fractures cf. groundwater springs) water pressures and hydraulic fracturing of the chert during rapid permafrost melting. A simple 1D model of this thermokarstic process is used to explore this mechanism, and it is proposed that the resultant anomalously high input of chert and sand into the valley during terminations caused pulsed aggradation until the end of the last glacial period (Fig. 5). It is also proposed that interglacial and interstadial incision may have been prevented by the over-sized and interlocking nature of the subangular chert clasts. This created an immobility threshold and was only overcome in the Lateglacial when confinement of the river caused an increase in fluvial power which meant that clast transportation and incision resumed. One result of this hydrogeologically controlled valley evolution was to provide a sequence of Palaeolithic archaeology within the gravels deposited over two MIS cycles., probably from sites located nearby on the braided floodplain (Brown et al., 2014a). This study demonstrates that uplift tectonics and climate alone do not fully determine Quaternary valley evolution and that lithological and hydrogeological conditions are a fundamental cause of variation in terrestrial Quaternary records and landform evolution. The direct implication for the JCWHS is that the cliff-line profile from West Down Beacon to Golden Cap is again the result of uplift and fluvial erosion of approximately $10 \mathrm{~km}$ probably since MIS 12 and this has also created the terraced nature of the coastal profile along with the differential effects of lithology. A further implication is that the inclined layer-cake, predominantly soft-rock geology of the region has not only profound effects on the coastal landforms and evolution but also the development of the catchments and valleys that drain through it, bisect it and create many cliff exposures.

\subsection{The Frome-Piddle and other smaller headwater system}

The Frome-Piddle system has received less recent attention to its Quaternary deposits, despite the large number of gravel terraces (c. 15) many of which contain archaeology from different periods (Wymer, 1999). The reason for discussing the two rivers together is that downstream of the village of Moreton the gravel terraces merge indicating that for most of the later Pleistocene the valley at the eastern end of the JCWHS was bounded by a single fluvial system. There is no recent sedimentbased dating available at present but the terraces have been correlated with the Stour and Avon systems to the east (Allen and Gibbard, 1993; Maddy, 1997; Westaway, 2002). The major indirect implication of studies the Frome-Piddle and Stour river terraces is that in the early Pleistocene their low gradients probably reflect their drainage into an easterly flowing Palaeo-Solent system. The increase in gradient of the terraces altitudinally below terrace 4, has been ascribed to the breaching of the Purbeck-Isle of Wight chalk ridge effectively creating the eastern termination of the JCWHS and Poole Harbour (Westaway et al., 2006). However, the remarkably large wave-cut platform 
forming Weymouth and Bournemouth-Christchurch Bays suggests that this breaching may have been much earlier and possibly pre-Quaternary.

In addition to the gravel terraces there are anecdotal and historical notes of Quaternary deposits including organic materials that have occasionally been observed from the valley fills of several of the smaller rivers including the Char and Brit or Bride (Edmonds pers. comm., West pers. comm.) but none has as yet been subject to excavation and scientific analyses. However, there are many finds of Palaeolithic stone tools in both the Frome-Piddle and adjacent Stour Valley terraces illustrating how these valleys acted a routeways for Palaeolithic hominins moving between the palaeo-coastline and inland areas particularly at times when the majority of the landscape was wooded (Cohen et al., 2012; Brown et al., 2013b)

\subsection{Discussion: Sea-levels, periglaciation and long-term coastal dynamics}

The JCWHS has some spectacular, and classic, coastal landforms including a large arch with low stacks (Durdle Door), sea caves (especially on the Isle of Portland), Europe's longest beach barrier system (Chesil Beach) and the text-book example of structural control on embayment development at Lulworth Cove associated with a dry valley system. With the exception of Chesil Beach (which is Holocene), the age of these erosional landforms is unknown. Although it is assumed they formed during the middle to late Holocene due to their on- going formation at today's sea level, it is not impossible that they originated in previous high-stands such as the last interglacial (Ipswichian/MIS 5e) or earlier and have been reactivated in the present interglacial. More detailed consideration of the coastal landform evolution of the JCWHS can be found in May (2017) in this volume. One critical link between the fluvial systems and depositional coastal systems, (particularly evident at Chesil Beach and the Portland raised beaches) is the large supply of pre-rounded flints, cherts and sandstones from the fluvial terraces truncated by coastal erosion, as well as from bedrock sources and particularly the Budleigh Salterton pebble beds.

The Isle of Portland is a critically important area as it is the only location along this coast where deposits from Quaternary high sea-levels have been preserved. This is due to uplift and interestingly the deposits also reveal a very strong periglacial legacy (Brown, 2016). Portland Bill is the classic location in Southern England for studies of Pleistocene raised beaches (Campbell et al., 1998b). Originally only one beach was recognised which was attributed to high global sea levels during the last interglacial: the Ipswichian (or Eemian in Europe) and which is now correlated with MIS 5e or 5.5. This beach at $6-10 \mathrm{~m}$ above present sea level and has been identified from many locations in the British Isles, although chronometric dating has been relatively sparse. It is now believed that there are at least three fossil beaches on Portland. The classic study by Davies and Keen (1985) used a combination of levelling, biostratigraphy and early amino acid racemization dating to show that the West and East raised beaches were probably of different ages. The West Beach (Fig. 6), which extends under the Admiralty Underwater Weapons Establishment (AUWE) consists of up to $2.5 \mathrm{~m}$ of well-sorted sandy gravel in as many as seven fining-upward units grading from pebbles to coarse sand. It only contains shelly fossils at the base and these include rocky-shore gastropods (Nucella lapillus, Littorina littorea and Patella spp.) and a number of species of the bivalve Cerastoderma. The East Beach, which crops out on the eastern cliff between Portland Bill and Longstone Open Quarries, comprises poorly-sorted and generally thin gravels, which are also heavily deformed by cryoturbation. Although this deformation is generally thought to be post-depositional, it is interesting to note there is also evidence of cryoturbation of the underlying Purbeck limestone. Since this lies beneath undeformed gravels an additional earlier phase of cryoturbation is likely. The deposits are richly fossiliferous and dominated by rocky shore gastropods (Littorina spp., Gibbula spp., Patella spp., Nucella lapillus) and the bivalve Turtonia minuta. Levelling shows that the base of 
the West Beach lies at $10.76 \mathrm{~m}$ OD and the base of the East Beach lies at $6.95 \mathrm{~m}$ OD. The amino acid racemisation $D / L$ ratios ( $D$-alloisoleucine: $L$-isoleicine) suggested that the East Beach is older than the West Beach and they correspond with MIS 7 (c. 210,000 BP) and MIS 5e (125,000 BP).

The difference in height between the beaches is most likely attributable to regional uplift in the midlate Pleistocene (Westaway, 2011). The head deposits which lie above the raised beach, comprise a succession of loams (loess), with calcareous nodules, which thicken inland. These sediments also display clear periglacial deformation (frost heaving) which is aligned downslope and which extends into the bedrock. This has been noted before (Pugh and Shearman, 1964) and recent observation by one of the authors (AGB) has confirmed the features as being only at the surface of the Purbeck Limestone and remarkably similar to surficial periglacial structures seen associated with bedrock deformation associated with raised beaches on Svalbard (Fig. 7). Indeed studies in the High Arctic have shown how periglacial processes and especially the interaction of permafrost, variable lithology, weathering and slope processes controls cliff evolution with wave action rejuvenating the system during high sea level stands producing high rates of cliff retreat (Strzelecki et al., 2017). Ostracods suggest the presence of brackish pools, so it is likely that these loams were deposited adjacent to a high sea level and, stratigraphically, should date to the last cold stage (Devensian). The new discovery of an intermediate raised beach on Portland (Gallois, 2013), and the revised chronostratigraphy on Portland, illustrates that around the southern British Isles and Ireland there are multiple wave-cut platforms and beach deposits of a variety of ages. Contrary to earlier interpretations they do not all date to interglacials with high eustatic sea levels. The relative role of isostatic depression and eustatic change in creating this 'staircase' of Late Pleistocene erosional and depositional coastal features has yet to be fully disentangled. A new source of borehole data associated with the East Weares, Portland Gas development may also provide valuable new information on the evolution of the northern side of Portland Island (Gallois, 2013).

In recent years, and partly informed by studies in the Arctic, it has been realized that long-term coastal evolution and glaciation are intimately connected (Lantuit and Pollard, 2008; Knight 2016; Strzelecki et al., 2017). This is not just through the repeated effects on eustatic sea level of approximately 80-120 m sea level equivalent being locked-up as ice in cold stages, but more subtly by a host of effects on both slope and fluvial processes over prolonged periods when the cliff-line was subaerial and not subjected to basal wave action. Our research in the Axe catchment identified numerous spring-line, arcuate basins, postulated to be the result of retrogressive thaw slumps, as well as the effects of periglacial brecciation on bedrock surfaces (Brown et al., 2014a). These observations and interpretations are entirely in line with recent thinking on periglacial landform evolution and concepts of cryo-conditioning greatly increasing erosion rates during periglaciation (Murton and Belshaw, 2011; Berthling and Etzelmüller, 2011). This work on the Axe is also supported by observations along the English coast to the east such as the Avon valley (Egberts et al., subm.) and detailed data from landslide complexes such as the Spittles at Lyme Regis could be used in testing these ideas (Murton and Belshaw, 2011).

The implications for the JCWHS coastline are clear: for the majority of the Pleistocene when relative sea levels were well below today's, the cliff-line must have been degraded by landsliding, valleybulging and thaw slumping related to the periglacial environment. Rates of movement would have been highest during periods of rapid permafrost melting as these rocks are highly susceptible to fluidization and failure onto the shoreline platform. Gallois (2010) has suggested that the deep effects of permafrost can be seen in structural disruption within the Lower Lias bedrock in the Lyme Regis area and it is known that the landsliding in Lyme Bay is largely the result of re-activation of late glacial systems which are also occasionally preserved under the sea (Brunsden et al., 1996; Gallois, $2009,2011)$. This sediment had to be eroded off shoreline platforms before wave action could reerode the cliff base. This sensitivity of soft rocks to the removal of toe-slope sediment accumulation 
can still be seen along much of the JCWHS and also to the east (Sunamura, 2015). The protective effects of periglaciation at lower relative sea levels, may also explain the apparent anomaly between measured rates of coastal erosion and long-term rates of coastline retreat which often seem to be an order of magnitude apart, varying from $10 \mathrm{~m} \mathrm{yr}^{-1}$ (Arctic) to $0.1 \mathrm{~m} \mathrm{yr}^{-1}$ for measured rates and under $0.01 \mathrm{~m} \mathrm{yr}^{-1}$ for geological rates (Cosgrove et al., 1998; Lobb and Brown, 2016; Guegan, 2015). The high relative sea levels of this and previous interglacials created an abrupt and spectacular landform that is beneficial for both stratigraphic geology and palaeontology. Along the coast from Chesil Beach to the Exe Valley there is a consistent but under researched succession, revealed in inland temporary exposures and cliff sections, showing a finer, reworked-Greensand clayey sand unit, and a coarse Greensand chert diamicton that is also of periglacial origin (Edmonds and Rose pers. comm. 2016). Sections at the tops of the cliff also hint at the presence of complex palaeosols. The extensive plateaus developed on Cretaceous Chalk or Greensand bedrock, have the potential to provide the most detailed histories of complex weathering available for the British Isles, but are so far unresolved, although correlation with palaeosols further west suggested possible pre-Oligocene (Eocene) ages (Isaac, 1983). Similarly the deep solution pits into the chalk revealed at Pinhay Quarry just inland of the coast near Lyme may relate to a pre or early phase of denudation of the chalk, as yet undated (Basell et al. 2011b). In contrast depositional coastal landforms such as Chesil Beach, the Fleet and the estuaries have been formed due to relative sea level rise in the early Holocene (May, 2017).

\subsection{Human impact and the Anthropocene}

There is no doubt that we are now living in a period in which human activity is a dominant force on the landscape, although when this began and how it will play out in the future remain areas of debate (Lane, 2015, Brown et al., 2016; Ganopolski et al., 2016; Zalasiewicz et al., 2017). The JCWHS has undergone significant human impact during the later Holocene including both coastal protection and development (May, 2017) but also more subtle effects through the siltation of its 6 estuaries (Exe, Otter, Sid, Axe, Brid, and Frome-Piddle) as well as the accommodation space created by the Chesil Beach and Weymouth barrier systems. There is strong historical evidence that this siltation increased rapidly over the last 2000-3000 years in the Exe and other estuaries, such as the Otter. Both the Roman port at Axmouth, and later probably Saxon port below Bridport, have become unnavigable necessitating the construction of a canal in the case of the Exe (Bennett et al. 2014) and total abandonment in the case of Axmouth.

More research is required but it is likely that all these estuaries started silting when relative sea level reached it current levels, but that siltation increased leading to channel contraction over the last 1000 years (Murphy, 2011: Bennett et al., 2013). The cause of this siltation is now agreed to be fundamentally anthropogenic, caused by the deforestation of river catchments, largely in the Bronze and Iron Ages (c. 4500 - 2000 BP; Brown et al., 2014b) and the adoption of intensive arable cultivation especially in the Medieval period (Macklin et al., 2010; Brown et al., 2013c; Brown et al., 2017). The nature and extent of these legacy sediments (sensu Walter and Merrits, 2008) varies along the JCWHS from high rates on the erodible Triassic sands and silts of East Devon to the largely soluble chalk in the Isle of Purbeck to the east. A record of this anthropogenic signal should also be preserved in both the Fleet behind Chesil Beach, behind the Weymouth Barrier, and in Poole Harbour where it is currently being investigated (Langdon pers. comm.). The human cost of this siltation was the decline of small ports along the JCWHC in favour of larger estuaries or harbours to the west (Exeter and Plymouth) and the east (Southampton). 


\subsection{Conclusions}

The JCWHS provides a remarkable section through a Quaternary landscape located for the majority of the last two million years in the periglacial zone just south of a waxing and waning ice margin and just north of an Atlantic inlet which eventually became the English Channel. As the coastline has migrated inland during both high and low sea levels, but by different geomorphic mechanisms, it has progressively truncated the fluvial and slope systems that constitute this part of southern England. This has created a typically step-like coastal profile, well exemplified by the coastal path at Ladram Bay which traverses a series of steps associated with changes in lithology (Otter Sandstone to Murcia Mudstone) and a series of sub-parallel strath terraces formed in the valley of this small headwater catchment (Fig. 8). Indeed it is the evolution of the cross-cutting fluvial landscape that has created the undulating height profile of the cliff-line of the JCWHS. Just as the cliffs expose Mesozoic rocks they also reveal gravel terraces and periglacial deposits that preserve this Quaternary story. The pebbles from the gravel terraces of these rivers, including Budleigh Salterton Pebblebed pebbles, are found in the Portland raised beaches, Chesil beach and along the south coast to Hastings, illustrating the coupling between the fluvial systems of the area and coastal landform development. This recent geological history is not just of academic interest as it is evidence of a subsiding western English Channel and a rapidly (relatively) rising upland. This determines the presence of high plateaus, deep valleys and, especially where the geology is appropriate, unstable hillside slopes. The input of Quaternary fluvial gravels into today's shoreline and beach deposits would have had, and continues to have implications for the rate of sea cliff erosion, since the morphology, grainsize and behaviour of a fronting beach will have a direct impact on the dissipation of energy of waves, particularly during winter storms (Sunamura, 2015; Bird and Lewis, 2015). The potential exists here for Quaternary studies to improve our understanding of landslip terrain and risk and the role of inheritance in these contemporary processes. Lastly recent studies of the gravel terraces along the rivers of the JCWHS have revealed that the landscapes Palaeolithic hominins moved in were of far lower relative relief than today's, with wide flat gravel-covered floodplains and shallow multi-channel rivers. Particularly during the warm-cold transitional periods and interstadials, these route ways were highly favorable for human migration into the British Isles from Northern France.

\section{Acknowledgements}

The authors would like to thank Historic England (formerly English Heritage) for all its support and encouragement and particularly P. Busby, V. Straker, and J. Last. Thanks must also go to J. Bennett, R. Scrivener, R. Gallois and all the landowners who allowed access to their land, in particular Aggregate Industries (formerly Bardon Aggregates) and Lafarge Ltd. Thanks also to the anonymous referees of this paper and those it reports on. This paper was greatly facilitated by the Ussher Society (Geosciences SW England) meeting at Weymouth in 2016, staff of the Jurassic Coast World Heritage Site, R. Edmonds and J. Rose.

\section{Figure and Table Captions}

Fig. 1. Map of the JCWHS with rivers and locations mentioned in the text with overlay of major present day catchment boundaries. Digital Elevation Model was derived from Ordnance Survey data via Digimap, OS Terrain 50m DTM (July 2017 version), under licence to Queen's University Belfast 
(QUB) and modelled in ArcMap 10.4.1 by LSB. Catchment Boundary data is from the CaBA Catchment Partnerships Jan 2017 produced by The Rivers Trust, based on Environment Agency data. UK and Ireland inset is the ESRI produced World Terrain Base map within ArcMap 10.4.1 under licence to QUB and annotated. All other data are annotations by the authors.

Fig. 2. (a) Location of the Exe and Axe valleys river catchments in southern England with river catchments coded by the number of BGS terraces recognised (after Brown et al., 2009) and ice limits, (b) generalised geological section of the Jurassic Coast, (b) a simplified geological cross-section along the Jurassic Coast with the Axe valley shown. The JCWHS area is highlighted by the box.

Fig. 3. A generalised model of the evolutionary sequence of the Middle Exe terrace staircase. The heights shown are in $\mathrm{m}$ above the modern floodplain surface. The grain size panels are illustrative only of a decrease in the clast size and increase in rounding of less resistant lithologies (white) and a relative increase in the abundance of more resistant lithologies (black) all within a sand matrix. Reproduced from Brown et al. (2010). The terrace chronology is derived from the OSL dates in Table 1.

Fig. 4. The long profile is re-drawn using some data from Campbell et al. (1998a), Basell et al. (2007), Brown et al. (2010) and this paper. Only the OSL dates with no analytical caveats are plotted for Chard Junction Quarry. Upper stippling is Upper Greensand lithologies and below Triassic Mudstones with the junction generalised from BGS mapping.

Fig. 5. Simplified model of para-fluvioperiglacial sediment input forced by permafrost melting of the Upper Cretaceous (Greensand) lithological sequence, (a) model representation, (b) the valley-side cross-sectional geology used in the model with present water table and (c) the model with frozen layer and flowlines after sequential melting. From Brown et al. (2014a).

Fig. 6. The West Beach on Portland Bill, which is located immediately below the fences of the Admiralty Underwater Weapons Establishment (AUWE). Image (c) Malcolm Hart.

Fig. 7 a. Frost heaved periglacial structures developed on Cretaceaous sandstone underlying the raised beach at Skartjørna in Svalbard in 2016 (photo AGB), b. the East raised beach at Portland showing the raised beach overlying cryoturbated Portland Limestone (photo AGB).

Fig. 8. Views northwestwards up the Otter valley showing the upper terrace level (broken white line) (a), across Ladram Bay from west to east (High Peak/Peak Hill) illustrating the typically stepped coastal profile associated with changes in lithology (Otter Sandstone to Murcia Mudstone) and a series of sub-parallel strath terraces (or benches) formed in the valley of this small headwater catchment, and (c) inset view from West Down Beacon to High Peak and (d) inset of cliff-top gravels on West Down Beacon to the south of Budleigh Salterton.

Table 1. $D_{r}, D_{e}$ and Age data of samples from Chard Junction ( $51^{\circ} \mathrm{N}, 3^{\circ} \mathrm{W}, 75 \mathrm{~m}$ O.D.). Samples CHAR01 to CHAR06 from Toms et al. (2008) Uncertainties in age are quoted at $1 \sigma$ confidence, are based on analytical errors and reflect combined systematic and experimental variability. All ages are expressed in thousands of years before 2010. The Westfield site data is from Bennett (2005).

\section{References}

Allen, L.G., Gibbard, P.L., 1993. Pleistocene evolution of the Solent River of southern England. Quaternary Science Reviews 12, 503-528.

Barber,K.E. (Ed.), 1987. Field Guide to Wessex and the Isle of Wight. Quaternary Research 
Association, Cambridge, 180pp.

Basell, L.S., Brown, A.G., Hosfield, R.T., 2007. The Palaeolithic Rivers of South-west Britain (PNUM 3847). Fieldwork Report (Phase II). English Heritage, London/ ADS York.

http://www.personal.rdg.ac.uk/_sgs04rh/SWRivers/Fieldwork\% 20Report.pdf.

Basell, L.S., Brown, A.G., Toms, P. T., 2011a. The Quaternary of the Exe Valley and Adjoining Areas. Field Guide. Quaternary Research Association, London, 163p.

Basell, L. S. Brown, A. G. Hosfield, R. T., Toms, P., 2011b. The Geoarchaeology of Palaeolithic Rivers of South West Britain. In Brown, A. G., Basell. L. S., Butzer, K. W. (Eds.) Geoarchaeology, Climate Change and Sustainability. Geological Society of America Special Publication 476, 23-36.

11

Bennett, J., 2005. Late Pleistocene and Holocene Fluvial Geomorphology of the River Exe, Devon. Unpub. PhD Thesis, University of Exeter, UK.

Bennett, J. A., Brown, A. G., Read, S. J., 2014. Exeter and Its River: Late Holocene Fluvial Geomorphology from Archaeology and Historical Sources. Proceedings of the Geologists Association $125,639-648$.

Bennett, J. A. Brown, A. G. Schwenninger J-L., Rhodes E. J., 2011. Holocene Channel Changes, and Geoarchaeology of the Exe River, Devon UK and the Floodplain Paradox. In Brown, A. G., Basell, L. S., Butzer, K. W. (Eds.) Geoarchaeology, Climate Change and Sustainability. Geological Society of America Special Publication 476, 135-152.

Berthling, I., Etzelmüller, B., 2011. The concept of cryo-conditioning in landscape evolution. Quaternary Research 75, 378-384.

Bird, E., Lewis, N. (Eds.) Beach Renourishment, Springer Briefs in Earth Sciences, Springer, New York, 137pp.

Briant, R.M., Coope, G.R., Preece, R.C., Keen, D.H., Boreham, S., Griffiths, H.I., Gibbard, P.L., 2004. Fluvial system response to late Devensian aridity, Baston, Lincolnshire, England. Journal of Quaternary Science 19, 479-495.

Briant, R. M., Bates, M.R., Hosfield, R., Wenban-Smith, F.F., 2009. The Quaternary of the Solent Basin and West Sussex Raised Beaches. Field Guild, Quaternary Research Association, London, 248pp.

Brown, A. G. 2004. The geoarchaeology of the Middle Nene valley. In Langford, H. E., Briant, R. M. (Eds.) Nene Valley Field Guide. Quaternary Research Association, Cambridge. 44-58.

Brown, A.G., 2012. Gulls, dates and axes: recent Quaternary research in South-West England. Geoscience in South-West England 13, 1-11.

Brown, A.G., 2016. Field excursion to the Isle of Portland on the 5th January, 2016. Geoscience in South-West England 14, 79-84.

Brown, A. G., Basell, L. S., Toms, P. T., 2014a. A stacked Late Quaternary fluvio-periglacial sequence from the Axe valley, Southern England with implications for landscape evolution and Palaeolithic Archaeology. Quaternary Science Reviews 29, 897-912. 
Brown, A. G., Powell, M., Basell, L. S. 2011. Recent work at Shapwick Grange Quarry and the Blackdown Hills Plateau. In L. S. Basell, L.S., Brown, A.G., Tomsm, P.S (Eds.) The Quaternary of the Exe Valley and Adjoining Area. Field Guide. Quaternary Research Association, London, 128-132.

Brown, A. G., Basell, L. S., Robinson, S., Burge, G. C., 2013a. Site Distribution at the Edge of the Palaeolithic World: A Nutritional Niche Approach. PLoS ONE 8(12), e81476, 1-14. archaeology. Quaternary Science Reviews 116, 1-16.

Brown, A. G., Basell, L. S., Toms, P. S., Scrivner, R. C., 2009. Towards a budget approach to Pleistocene terraces: preliminary studies using the River Exe in South West England. Proceedings of the Geologists' Association. 120, 275-281.

Brown, A. G., Toms, P, Carey, C., Rhodes, E., 2013b. Geomorphology of the Anthropocene: timetrangressive discontinuities of human-induced alluviation. The Anthropocene 1, 3-13.

Brown, A. G., Basell, L.S, Toms, P.S., Bennett, J., Hosfield, R.T., Scrivener, R.C., 2010. Late Pleistocene Evolution of the Exe Valley. A Chronstratigraphic Model of Terrace Formation and its Implications for Palaeolithic Archaeology. Quaternary Science Reviews 29, 897-912.

Brown, A. G., Hawkins, C., Ryder, L., Hawken, S., Griffith, F. M., Hatton, J., 2014b. Vegetation history and the making of Devon landscapes. I. The Blackdown Hills. Boreas 43, 834-855.

Brown, A.G., Tooth, S., Bullard, J.E., Thomas, D.S.G., Chiverrell, R.C., Plater, A.J., Murton, J.,Thorndycraft, V.R., Tarolli, P., Rose, J., Wainright, J., Downs, P., 2017. The Geomorphology of The Anthropocene: Emergence, Status and Implications. Earth Surface Processes and Landforms 42, 7190.

Brown, A. G., Davis, S. R., Hatton, J, O’Brien, C., Reilly, F., Taylor, K., Dennehy, E, O'Donnell, L., Bermingham, N., Timpany, S., Tetlow, E., Wynne, S., 2016. The Environmental Context and Function of Burnt-Mounds: Palaeoenvironmental Studies of Irish Fulacht Fiadh. Proceedings of the Prehistoric Society 82, 259-290.

Brunsden, D., Coombe, K., Goudie, A.S.,Parker, A.G., 1996. The structural geomorphology of the Isle of Portland, southern England. Proceedings of the Geologists' Association 107, 209-30.

Campbell, S., Stephens, N., Green, C.P., Shakesby, R.A., 1998. Broom gravel pits. In: Campbell, S., Hunt, C.O., Scourse, J.D., Keen, D.H., Stephens, N. (Eds.), Quaternary of South-west England, Geological Conservation Review Series, vol. 14. Chapman \& Hall, London, 307-318.

Campbell, S., Scourse, J.D., Hunt, C.O., Keen, D.H., Stephens, N., 1998. Quaternary of South-West England. Geological Conservation Review Series No. 14, Kluwer, London, 439 pp.

Cohen, K.M., MacDonald, K., Joordens, J.C.A., Roebroeks, W. \& Gibbard, P.L., 2012. Earliest occupation of north-west Europe: A coastal perspective. Quaternary International 271, 70-83. Cosgrove, A.R.P., Bennett, M.R., Doyle, P. 1998. Causes of beach erosion. In Bird, E., Lewis, N. (Eds.) Beach Renourishment, Springer Briefs in Earth Sciences, Springer, New York, pp. 7-28.

Davies, K.H., Keen, D.H., 1985. The age of Pleistocene marine deposits at Portland, Dorset. Proceedings of the Geologists' Association 96, 217-225.

Durrance, E.M., 1969.The buriedchannels of the Exe.Geological. Magazine 106, 174-189. 
Durrance, E.M., 1980. A review of the geology of the Exe estaury. In: Boalch, G.T. (Ed.), Essays on the Exe Estuary, special vol. 2. The Devonshire Association for the Advancement of Science, Literature and Art, Exeter, pp. 41-72.

Edwards, R.A., Scrivener, R.C., 1999. Geology of the Country around Exeter. Memoir for the 1:50,000 Geological Sheet 325 (England and Wales) HMSO, London.

Elderfield, H., Ferretti, P., Greaves, M., Crowhurst, S., McCave, I.N., Hodell, D., Piotrowski, A. M., 2010.

Evolution of Ocean Temperature and Ice Volume Through the Mid-Pleistocene Climate Transition. Science 337, 704-709.

Gallagher, C., 2014. Retrogressive thaw slumps. In Hergitai, H., Kereszturi, A. (Eds.) Encyclopedia ofPlanetary Landforms. Springer-Science, New York, 1-6.

Gallois, R.W., 2009. A recent large landslide at The Spittles, Lyme Regis, Dorset and its implications for the stability of adjacent areas. Geosciences in South West England 12, 101-108.

Gallois, R.W., 2010. Large scale periglacial creep folds in Jurassic mudstones on the Dorset coast, UK. Geosciences in South-West England 12, 223-232.

Gallois, R.W., 2013. A concealed sea cliff and low-stand wave-cut platform on the Island of Portland, UK. Geoscience in South-West England 13, 222-227.

Ganopolski, A., Winkelmann, R., Schellnhuber, H.J., 2016. Critical insolation -CO2 relation for diagnosing past and future gløacial inception. Nature 529, 200-203.

Gibbard, P.L., Lewin, J., 2003. The history of the major rivers of southern Britain during the Tertiary. Journal of the Geological Society 160, 829-845.

Green, C.P., 1974. Pleistocene gravels of the River Axe in south-western England, and their bearing on the southern limit of glaciation in Britain. Geol. Mag. 111, 213-220.

Green, C.P., 2013. Broom and the Axe Valley in the Middle Pleistocene. In: Hosfield, R., Green, C.P. (Eds.), Quaternary History of Palaeolithic Archaeology in the Axe Valley at Broom, South West England. Oxbow, Oxford, pp. 165-169.

Guegan, E., 2015. Erosion of permafrost affected coasts: rates, mechanisms and modelling. Doctoral thesis at the Norwegian University of Science and Technology (NTNU), pp. 328.

Hosfield, R., Green, C.P. (Eds.), 2013. Quaternary History of Palaeolithic Archaeology in the Axe Valley at Broom, South West England. Oxbow, Oxford, 384pp.

Hughes, P. D., Gibbard, P. L., 2014. A stratigraphical basis for the Last Glacial Maximum (LGM). Quaternary International 383, 174-185.

Isaac K.P., 1983. Tertiary lateritic weathering in Devon, England, and the Palaeogene continental environment of South-west England. Proceedings Geologists' Association 94, 105-114.

Kidson, C., 1962. Denudation chronology of the river Exe. Transactions of the Institute of British Geographers 31, 43-66. 
Knight, J., 2016. Deglaciation of the Northern Irish Sea Basin. In Coxon, P., McCarron, S., Mitchell, F. (Eds.) Advances in Irish Quaternary Studies. Volume 1 of the series Atlantis Advances in Quaternary Science, Springer, London, pp. 151-180.

Lane, P.J., 2015. Archaeology in the age of the Anthropocene: A critical assessment of its scope and societal contributions. Journal of Field Archaeology 40, 485-498.

Lantuit, H., Pollard, W.H., 2008. Fifty years of coastal erosion and retrogressive thaw slump activity on Herschel Island, southern Beaufort Sea, Yukon Territory, Canada. Geomorphology 95, 84102.

Lobb, M., Brown, A.G., 2016. Terrestrial Laser Scanning and Coastal Erosion at Low Hauxley. In Waddington, C., Bonsall, C. (Eds.) Archaeology and environment on the North Sea littoral: A case study from Low Hauxley. Oxbow Books, Oxford, pp. 291-301.

Lewin, J. and Gibbard, P.L., 2010. Quaternary river terraces in England: Forms, sediments and processes. Geomorphology 120, 293-311.

Macklin, M.G., Jones A., Lewin J., 2010. River response to rapid Holocene environmental change: evidence and explanation in British catchments. Quaternary Science Reviews 29, 13-14.

Maddy, D., 1997. Uplift-driven valley incision and river terrace formation in southern England. Journal of Quaternary Science 12, 539-545.

May, V. 2017. The submarine landscape of the "Jurassic Coast" World Heritage Site, Dorset, UK and Setting. Proceedings of the Geologist Association in press.

Murphy, P., 2011. The English Coast: A History and a Prospect. Bloomsbury, London, 298pp.

Murton, J.B., Belshaw, R.K., 2011. A conceptual model of valley incision, planation and terrace formation during cold and arid permafrost conditions of Pleistocene southern England. Quaternary Research 75, 385-394.

Pugh, M.E., Shearman, D.J., 1964. Cryoturbation Structures at the South End of the Isle of Portland. Proceedings of the Geologists Association 78, 464-471.

Sanderson, D.J., Dix, J.K., Westhead, K.R., Collier, J.S. 2017. Bathymetric mapping of the coastal and offshore geology and structure of the Jurassic Coast, Weymouth Bay, UK. Journal of the Geological Society $174,498-509$.

Strzelecki, M.C., Kasprzak, M., Lim, M., Swirad, Z.M., Jaskólski, M., Pawłowski, Ł., Modzel, P. 2017. Cryo-conditioned rocky coast systems: A case study from Wilczekodden, Svalbard. Science of The Total Environment, 607-608, 443-453.

Sunamura, T., 2015. Rocky coast processes: with special reference to the recession of soft rock cliffs. Proceedings of the Japanese Academy Series B 91, 481-500.

Toms, P.S., Brown, A.G., Basell, L.S., Hosfield, R.T., 2008. Palaeolithic Rivers of Southwest Britain: Optically Stimulated Luminescence Dating of Residual Deposits of the Proto-Axe, Exe, Otter and Doniford. English Heritage Research Department Report Series, 2e2008. 
Toms, P. S., Brown, A. G., Basell, L. S., Duller, G. A., Schweninninger, J-L., 2011. Optical dating of the deposits of the proto-Axe at Chard Junction Quarry, Somerset. Report of the University of Gloucestershire Geochronology Laboratories, 52p.

Toms, P., Brown, A. G., Basell, L., Duller, G., Schwenninger, J-L., 2013. Chard Junction Quarry, Somerset. Optical Stimulation Luminescence Dating of the Proto-Axe. Research Report Series no. 72013, English Heritage.

Walter, R.C., Merritts D.J., 2008. Natural streams and the legacy of water-powered mills. Science 319, 299-304.

Westaway, R., 2010. Cenozoic uplift of southwest England. Journal of Quaternary Science 25, 419432.

Westaway, R., 2011. Quaternary fluvial sequences and landscape evolution in Devon and Somerset. In Brown, A.G., Basell, L.S., Toms, P. T., (Eds.). The Quaternary of the Exe Valley and Adjoining Areas. Field Guide. Quaternary Research Association, London, pp. 163.

Westaway, R. W. C., Bridgland, D. R., White, M., 2006. The Quaternary uplift history of central southern England: evidence from the terrace of the Solent River system and nearby raised beaches. Quaternary Science Reviews 25, 2212-2250.

Wymer, J.J., 1999. The Southern River Project. English Heritage/Wessex Archaeology, Salisbury.

Zalasiewicz, J. Waters, C.N., Wolfe, A.P., Barnosky, A.D., Cearreta, A., Edgeworth, M., Ellis, E.C., Fairchild, I.J., Gradstein,F.M., Grinevald, A., Haff, P., Head, M.J., Ivar do Sul, J.A., Leinfelder, R., McNeill, J.R., Oreskes, N., Poirier, C., Revkin, A., Richter, D., Steffen, W., Summerhayes, C., Syvitski, J.P.M., Vidas, D., Wagreich, M., Wing, S., Williams, M. 2017. Making the case for a formal Anthropocene Epoch: an analysis of ongoing critiques. Newsletter on Stratigraphy 50, 205-226. 


\begin{tabular}{|c|c|c|c|c|c|c|}
\hline River/Site & $\begin{array}{l}\text { Lab } \\
\text { Code }\end{array}$ & $\begin{array}{l}\text { Site Surface } \\
\text { Elevation }(\mathrm{m})\end{array}$ & $\begin{array}{l}\text { Overburden } \\
\text { (m) }\end{array}$ & $\begin{array}{l}\text { Total } D_{r} \\
\left(G y \cdot k a^{-1}\right)\end{array}$ & $\begin{array}{l}D_{e} \\
\text { (Gy) }\end{array}$ & $\begin{array}{l}\text { Age } \\
\text { (ka) }\end{array}$ \\
\hline \multicolumn{7}{|l|}{ River Axe } \\
\hline & GL02082 & \multirow{12}{*}{50} & 4.0 & $1.72 \pm 0.11$ & $503.3 \pm 27.8$ & $293 \pm 24$ \\
\hline & GL02085 & & 20.0 & $1.27 \pm 0.08$ & $353.4 \pm 21.4$ & $279 \pm 24$ \\
\hline & GL03004 & & 2.7 & $1.08 \pm 0.05$ & $288.3 \pm 19.1$ & $268 \pm 22$ \\
\hline Broom: & GL03005 & & 2.9 & $1.45 \pm 0.07$ & $326.8 \pm 17.3$ & $226 \pm 16$ \\
\hline Fortfield Farm & GL03006 & & 2.8 & $1.36 \pm 0.08$ & $375.9 \pm 27.1$ & $277 \pm 25$ \\
\hline \multirow[t]{4}{*}{ Gravel } & GL03007 & & 3.0 & $1.19 \pm 0.06$ & $324.0 \pm 20.8$ & $271 \pm 22$ \\
\hline & GL03008 & & 1.0 & $1.45 \pm 0.07$ & $352.8 \pm 18.9$ & $244 \pm 18$ \\
\hline & GL03009 & & 1.1 & $1.27 \pm 0.06$ & $343.0 \pm 18.6$ & $270 \pm 19$ \\
\hline & GL03010 & & 15.0 & $1.61 \pm 0.12$ & $380.6 \pm 28.0$ & $237 \pm 25$ \\
\hline Broom: & GL02083 & & 20.0 & $1.61 \pm 0.08$ & $461.5 \pm 28.0$ & $287 \pm 22$ \\
\hline Sand \& Silt & GL08084 & & 20.0 & $1.73 \pm 0.10$ & $483.0 \pm 21.0$ & $279 \pm 20$ \\
\hline Bed & GL03011 & & 16.2 & $1.84 \pm 0.10$ & $546.0 \pm 44.8$ & $297 \pm 30$ \\
\hline \multirow{10}{*}{$\begin{array}{l}\text { Chard } \\
\text { Junction }\end{array}$} & GL06011 & \multirow{10}{*}{75} & 2.5 & $0.96 \pm 0.05$ & $90.2 \pm 6.8$ & $94 \pm 9$ \\
\hline & GL06010 & & 4.3 & $1.54 \pm 0.10$ & $268.5 \pm 22.0$ & $174 \pm 18$ \\
\hline & GL06013 & & 4.5 & $1.09 \pm 0.07$ & $298.6 \pm 19.2$ & $274 \pm 25$ \\
\hline & GL06057 & & 6.7 & $1.02 \pm 0.07$ & $375.3 \pm 24.6$ & $367 \pm 35$ \\
\hline & GL06058 & & 7.0 & $1.12 \pm 0.08$ & $318.3 \pm 33.3$ & $284 \pm 36$ \\
\hline & GL09119 & & 8.8 & $2.26 \pm 0.12$ & $529.9 \pm 24.5$ & $235 \pm 17$ \\
\hline & GL10002 & & 13.1 & $0.86 \pm 0.05$ & $229.4 \pm 16.2$ & $268 \pm 25$ \\
\hline & GL10016 & & 14.8 & $1.24 \pm 0.09$ & $257.7 \pm 19.0$ & $208 \pm 21$ \\
\hline & GL08046 & & 15.0 & $1.56 \pm 0.11$ & $521.4 \pm 41.5$ & $334 \pm 36$ \\
\hline & GL08044 & & 15.2 & $1.63 \pm 0.14$ & $477.2 \pm 45.1$ & $292 \pm 37$ \\
\hline \multicolumn{7}{|l|}{ River Exe } \\
\hline Worth Wood & $\mathrm{X} 218 \mathrm{~b}$ & 20 & 1.7 & $2.81 \pm 0.13$ & $63.1 \pm 4.8$ & $22 \pm 2$ \\
\hline \multirow[t]{2}{*}{ Princesshay } & GL05063 & 40 & 0.3 & $2.74 \pm 0.16$ & $116.6 \pm 11.9$ & $43 \pm 5$ \\
\hline & GL06033 & 60 & 0.8 & $2.98 \pm 0.16$ & $35.8 \pm 4.2$ & $12 \pm 2$ \\
\hline \multirow[t]{2}{*}{ Yellowford } & GL06035 & 60 & 0.8 & $3.02 \pm 0.12$ & $178.6 \pm 44.1$ & $182 \pm 26$ \\
\hline & GL06032 & 60 & 1.2 & $2.68 \pm 0.15$ & $39.0 \pm 7.0$ & $15 \pm 3$ \\
\hline Uffculme & X1299 & 91 & 1.3 & $2.31 \pm 0.14$ & $91.0 \pm 3.3$ & $39 \pm 3$ \\
\hline
\end{tabular}




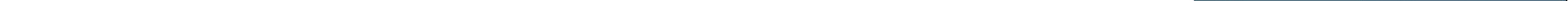


Fig. 2.

a.

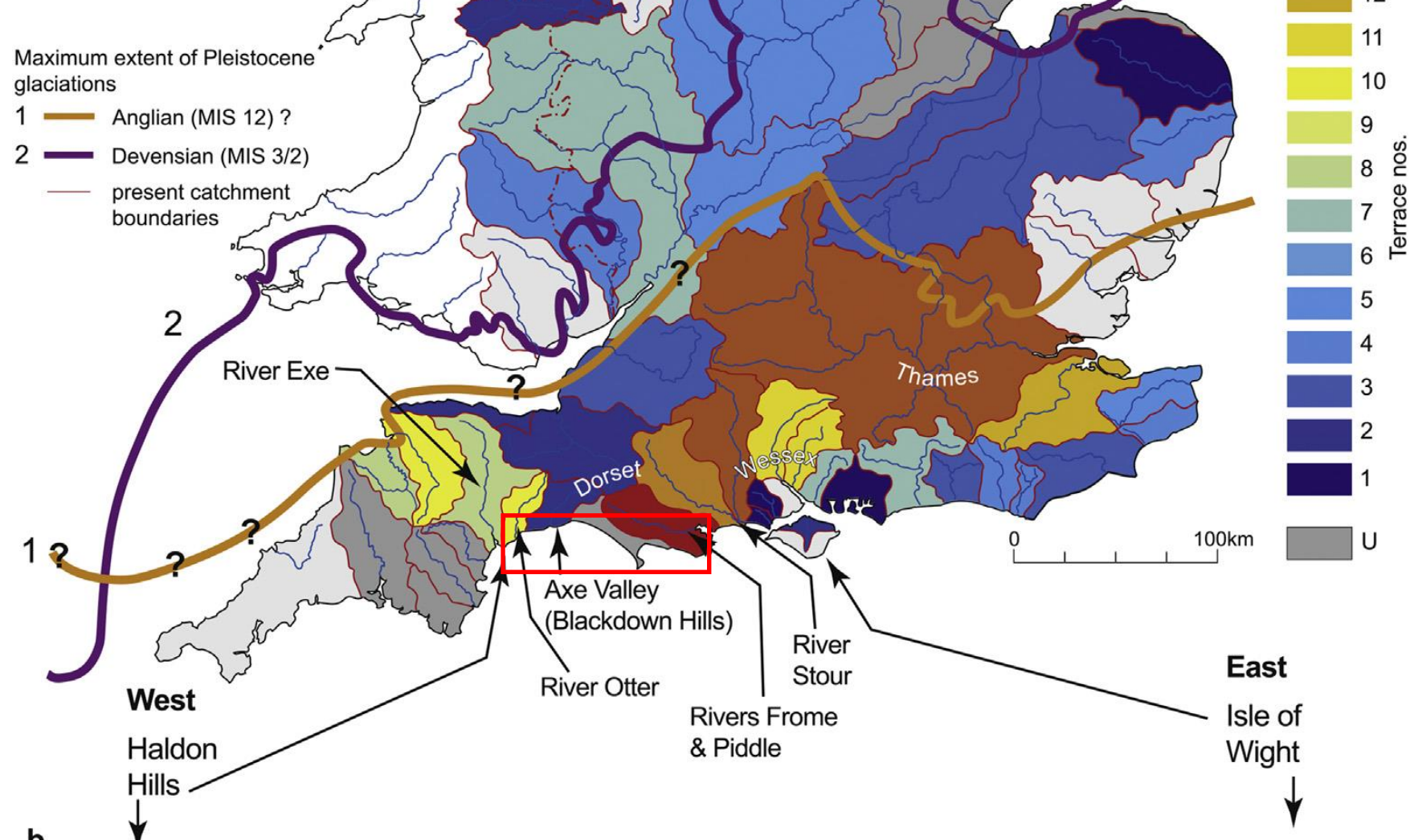

b. $\downarrow$

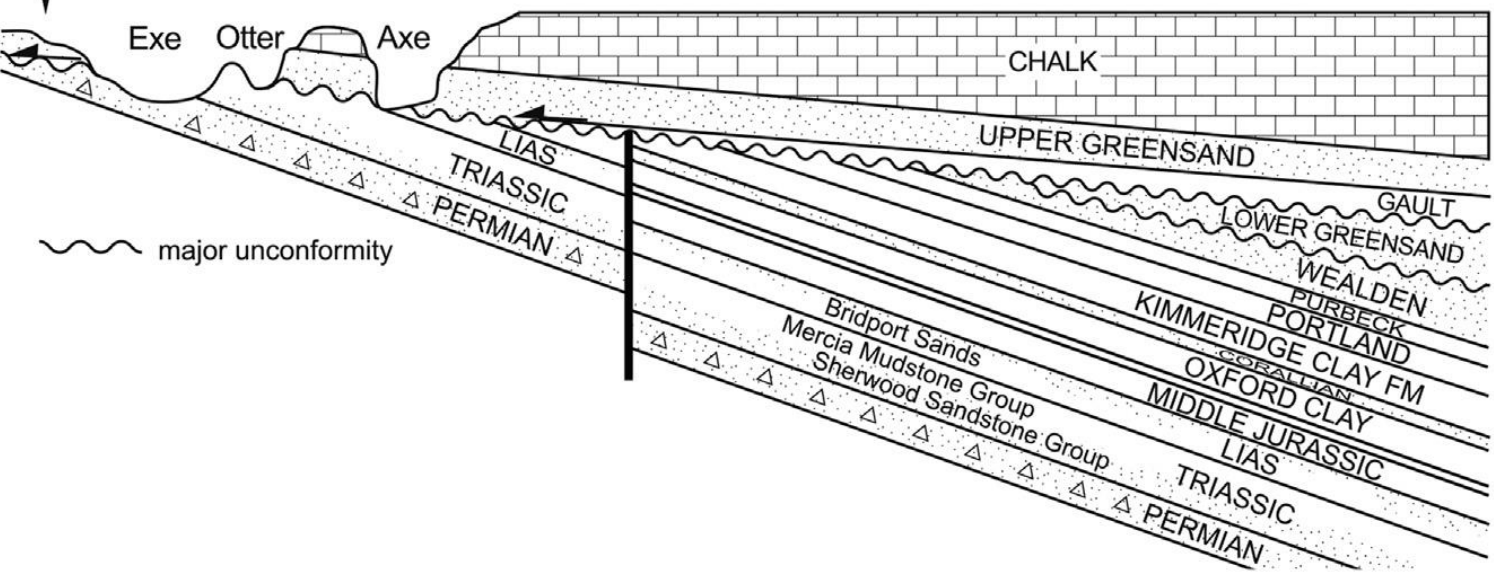


Figure 3

Fig. 3
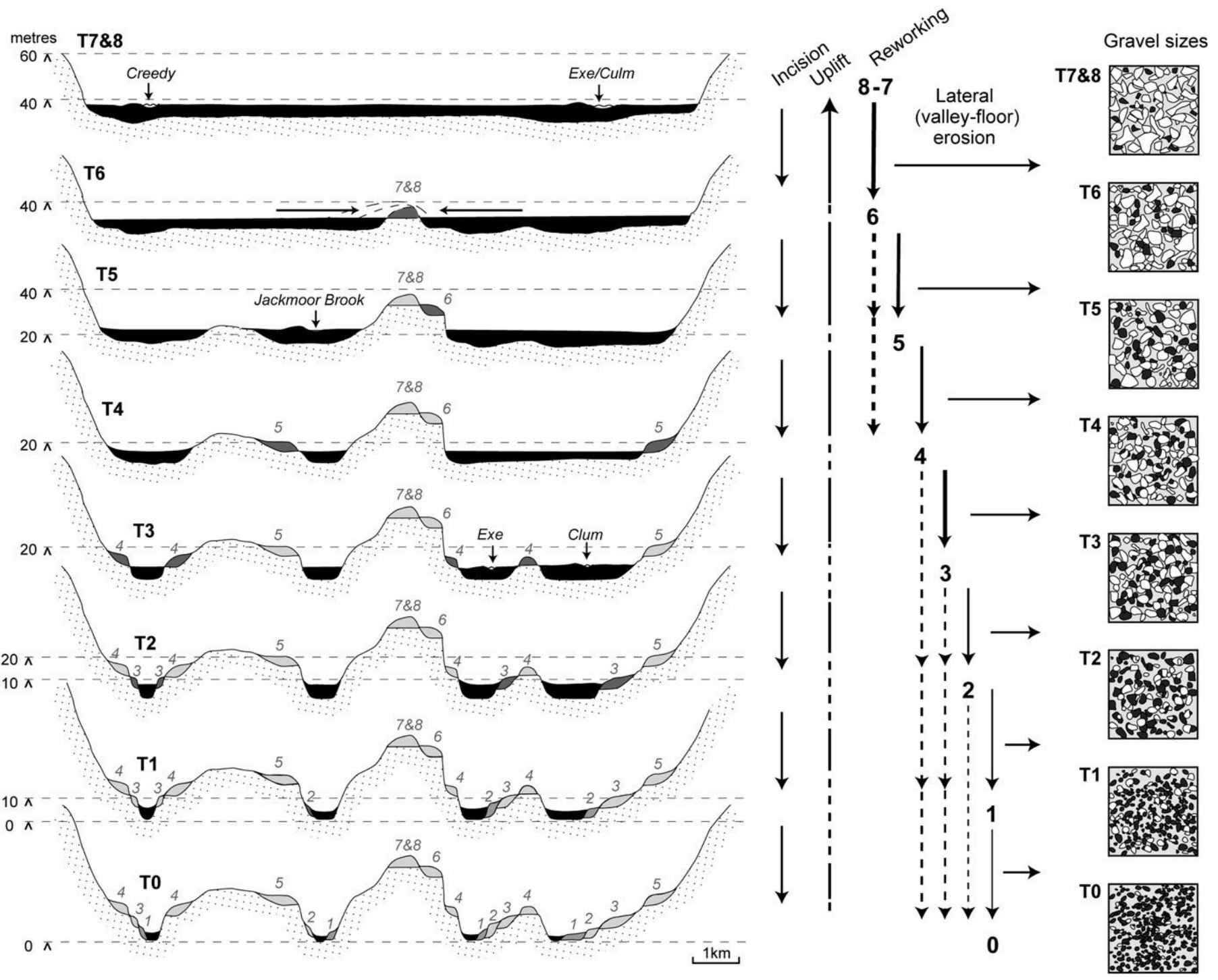
Fig. 4

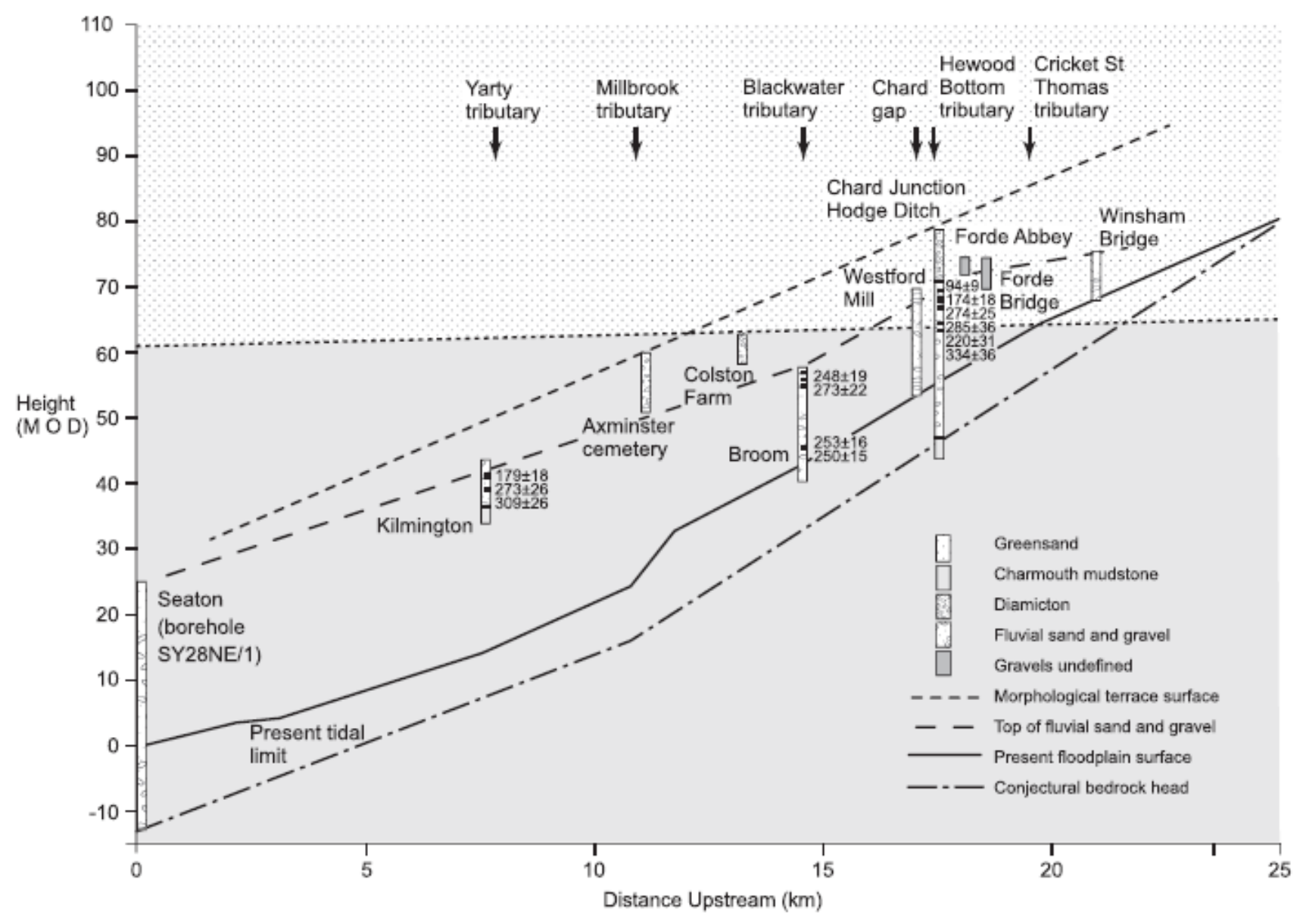


Figure 6
Fig. $\epsilon$

Figure 6
Fig. 6

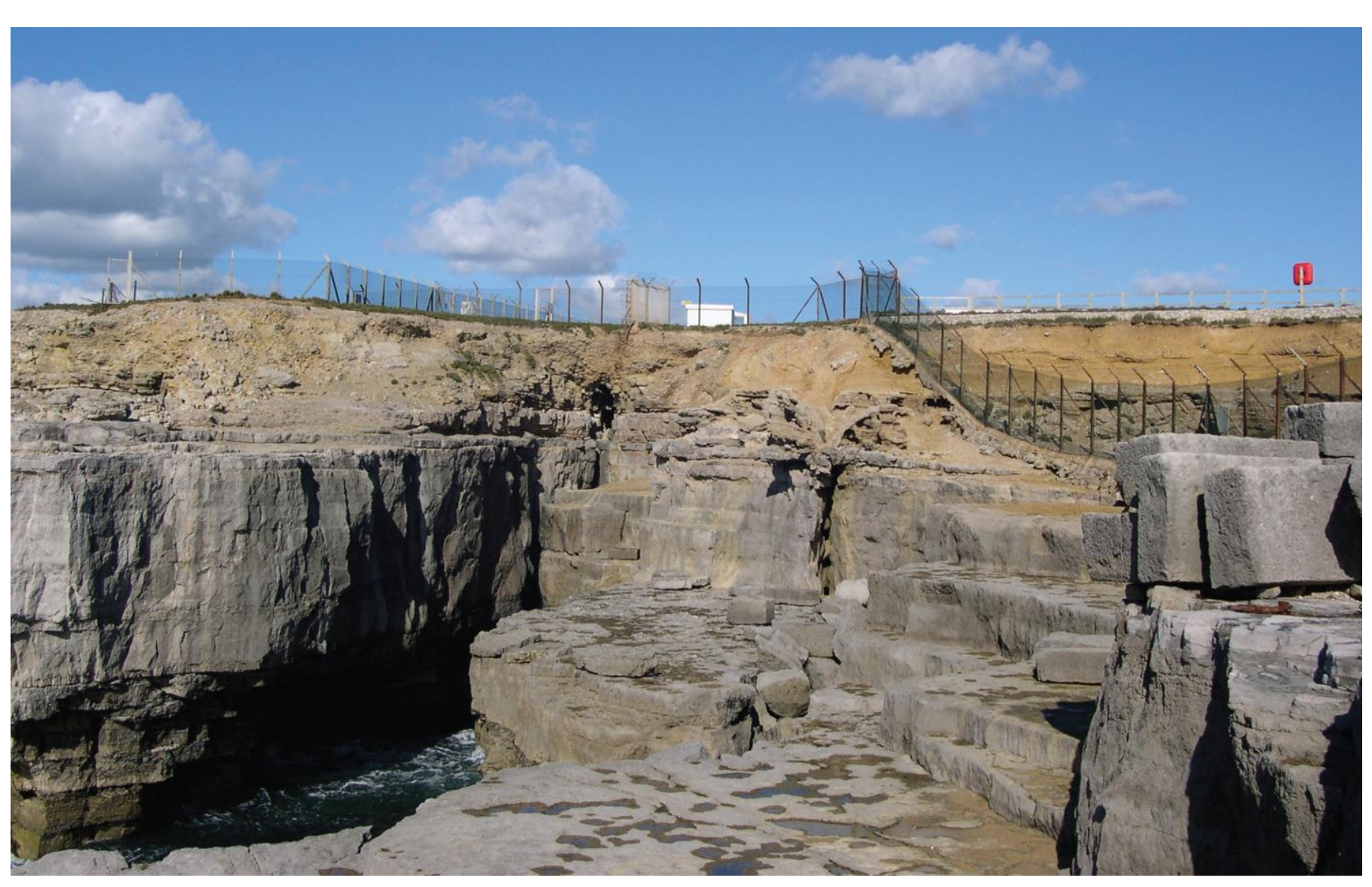




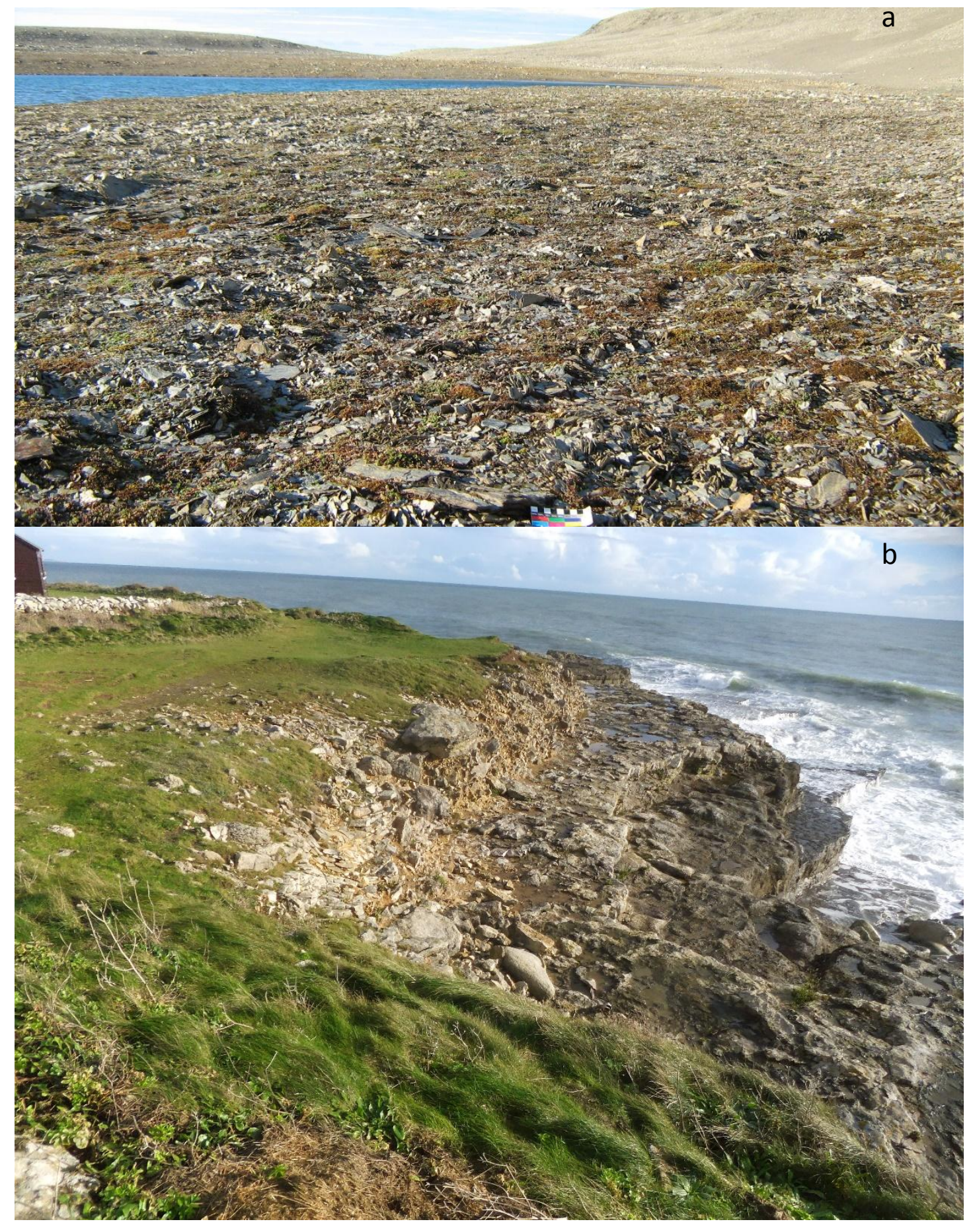

Figure 7 New

5

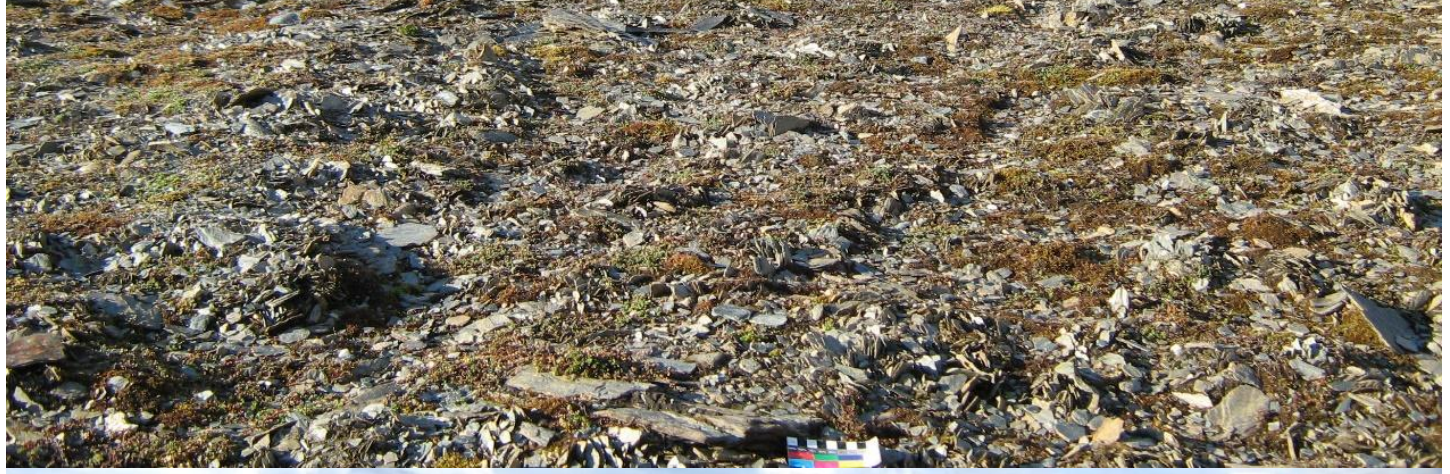

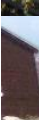
.

.




\section{Click here to download high resolution image}

$$
\text { a }
$$

High Peak

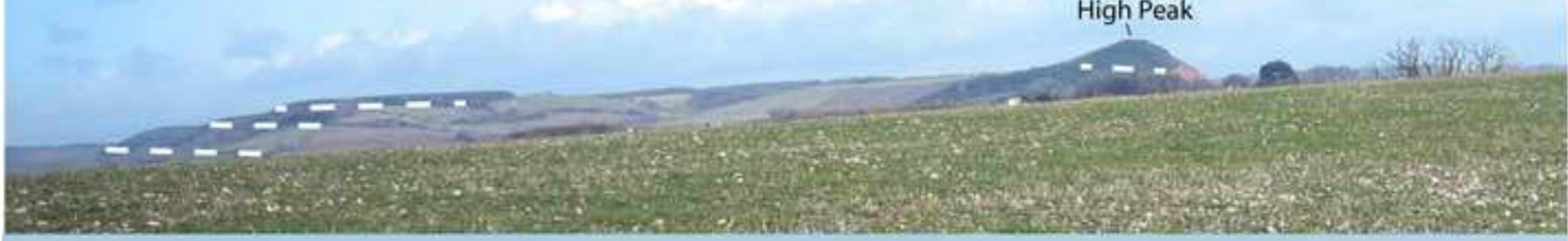

b

High Peak

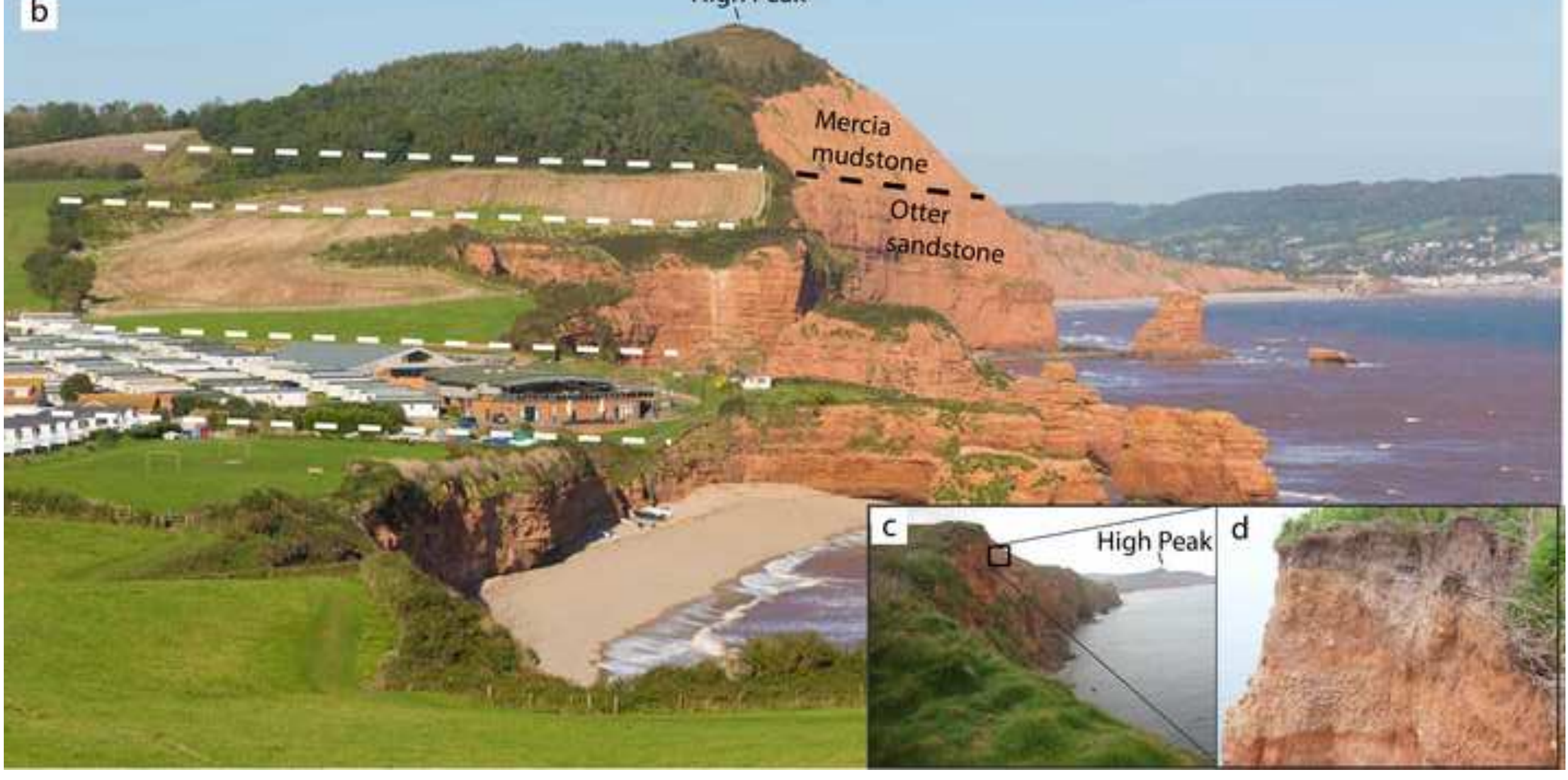

